\title{
Effect of Bioactive Compounds of Avocado (Persea americana) Fruit Powder on Hypercholesterolemic Rats: Biological and Biochemical Studies
}

\author{
Amal N. Z. Nasef ${ }^{1}$, Asmaa H. Ahmed ${ }^{2}$
}

\begin{abstract}
This study was conducted to show the effect of different concentrations of avocado fruit powder on some biological and biochemical parameters of hypercholesterolemic rats. Thirty male Sprague Dawley rats weighing $(180 \pm 20 \mathrm{~g}$ B.Wt) were divided into two main groups . The first main group (6 rats) fed on basal diet as (control negative group ve), while the second main group ( 24 rats) was classified into four groups (6 rats each) fed on $1.5 \%$ cholesterol plus $10 \%$ sheep ghee for 15 days to induce hypercholesterolemia. One of these group was considered (control positive group +ve) and the other groups fed $10 \%$ , $15 \%$ and $25 \%$ avocado fruit powder, respectively, for 28 days. The chemical composition and bioactive compounds of avocado fruit were determined. The biological parameters as BWG, FER, and FI and weight of internal organs determined and biochemical parameters as lipid profile, liver function, kidney function and histological examination of heart, liver and kidney were performed. The results indicated that there was a significant increase in lipid profile except HDL, liver function and kidney function in the positive control (+ve) group. It can be noted that all treatments of avocado fruit powder improved the previous parameters. The best treatment was observed in the group fed on $25 \%$ avocado powder.
\end{abstract}

Keywords: Avocado fruit - Hypercholesterolemia biological and biochemical parameters- lipid profile bioactive compounds.

\section{INTRODUCTION}

Cholesterol is an essential substance with several physiological functions; however, when its level elevates substantially in the blood (hypercholesterolemia) that leads to various deleterious conditions such as atherosclerosis and related cardiovascular diseases (CVD) (Roman et al., 2015).

Familial hypercholesterolemia (FH) is caused by a co-dominantly inherited defect in the synthesis or function of the LDL receptor (LDLR) that reduces the catabolism of LDL particles and markedly increases plasma cholesterol concentrations (Haralambos et al., 2016) .

DOI: 10.21608/ASEJAIQJSAE.2019.53811

${ }^{1}$ Dept. of Nutrition \& Food Science, Faculty of Home Economics, Menoufia University, Egypt.

${ }^{2}$ Dept. of Home Economics, Faculty of Specific Education,

Menoufia University, Egypt

Corresponding Author: amal_nasef2010@yahoo.com

Tel: 01020608340

Received September 01, 2019, Accepted September 30, 2019
Hypercholesterolaemia is one of the major causes of atherosclerosis, although there are many causes, hypercholesterolaemia is the permissive factor that allows other risk factors to operate and the incidence of coronary heart disease is usually low where population plasma cholesterol concentrations are low (Aljenedil et al., 2018).

Avocado (Persea americana) is highly nutritious fruit, having curative effects for many human ailments, from diarrhea to high blood pressure due to assortment of vitamins, high in monounsaturated fat and potassium (Hamouda et al.,2016).

Avocado has low sugar content $(0.2 \mathrm{~g}$ in a half unity). D-mannoheptulose is the main kind of sugar found in the fruit which seems to lack nutritional properties, appearing to be one more phytochemical component of the avocado (Wang et al., 2015)

The Persea americana fruit was most effectively improved liver functions and antioxidant system and had an important phenolic and flavonoid compound (Mahmoud and Rezq,2013).

Avocado had low caloric and a lot of fiber, $75 \%$ of fiber's avocado contents are considered insoluble and $25 \%$ are soluble so that avocado may improve hypercholesterolemia and may be useful in the treatment of hypertension and type 2 diabetes mellitus, avocado plays an important role in the cardiovascular health (Weschenfelder et al., 2015).

Therefore, the objective of this study was to assess the therapeutic effects of avocado fruit powder on hypercholesterolemic rats and the effects on metabolic and improve liver and kidney functions.

\section{MATERIALS AND METHODS}

\section{A- Materials:}

- Fresh avocado fruits used in this study were purchased from the local market Shiben El-Kom City, Menoufia Governator, Egypt. 
-Cholesterol, was purchased from Sigma Chemical Co. Casein, cellulose, and choline chloride powder were obtained from Morgan Co. Cairo, Egypt.

-Animals: Thirty mature male albino rats of SpragueDawley strain weighing $180 \pm 20$ g., were obtained from Vaccine and Immunity Organization, Ministry of Health, Helwan Farm, Cairo, Egypt.

\section{B- Methods:}

\section{Preparation of Avocado Fruit Powder:}

Avocado fruits were washed with running water. Then they have been carefully refined to get the edible part, and it was cut to thin slices then minced and sun dried, flowed by milling and kept in polyethylene bags at freezing temperature until using.

\section{Determination of chemical composition and bioactive compounds of avocado:}

Moisture, protein, fat, fiber, ash and minerals were determined according to AOAC (2012). Carbohydrate was calculated by difference. Identification of phenolic compounds were assessed by HPLC according to the method determined outlined by Radovanović et al. (2010).

\section{Determination of some Biological parameters}

During the experimental period, the diet consumed was recorded every day, and body weight recorded every week. The body relative weight gain (BWG\%) and feed efficiency ratio (FER) were determined according to Champman et al. (1959) using the following equations.

$$
\begin{aligned}
& \text { B.W.G. } \%=\frac{(\text { Final weight }- \text { Initial weight }) \times 100}{\text { Initial weight }} \\
& \text { FER }=\frac{\text { Body weight gain }(\mathrm{g} / \text { day })}{\text { Feed intake }(\mathrm{g} / \text { day })}
\end{aligned}
$$

\section{Experimental design}

The rats were divided into 5groups $(n=6)$ one of them used as negative control (-ve) while other groups had given $1.5 \%$ cholesterol plus 10\% sheep ghee for 15 days according to AIN (1993), as a positive control( $+\mathrm{ve}$ ) group and the other groups fed three doses of avocado powder (10,15 and 25\%) for 28 days.

\section{Blood samples}

At the end of the experiment period, blood samples were collected after $12 \mathrm{~h}$ fasting from the portal vein; the rats were sacrificed under ether anesthesia. Blood samples were received into clean dry centrifuge tubes and left to clot at room temperature, then centrifuged for $10 \mathrm{~min}$ at $3000 \mathrm{rpm}$ to separate the serum. Serum was carefully aspirated and transferred into clean covet tee tubes and stored frozen at $-20^{\circ} \mathrm{C}$ for analysis (Malhotra, 2003).

\section{Determination of some biochemical parameters}

The levels of serum creatinine and urea were estimated according to the method of Jendrassik and Grof (1983) and Patton and Crouch (1977), respectively. Serum levels of alanine aminotransferase (ALT) and aspartate aminotransferase (AST) were assayed by the methods of Srivastava et al. (2002), and Chawla (2003), respectively. The serum levels of total cholesterol (TC), triglyceride (TG) and high-density lipoprotein (HDL-c) were determined by methods of Allain et al. (1974), Fossati and Prencipe (1982) and Demacker et al. (1980), respectively. The determination of low-density lipoprotein cholesterol (LDL-c), very low-density lipoprotein cholesterol (VLDL-c) and Atherogenic Index (AI) were carried out according to the methods of Lee and Nieman (1996) as follows:

$$
\begin{aligned}
& \text { VLDL-c }=\mathrm{TG} / 5 . \\
& \text { LDL-c }=\text { Total cholesterol }-(\text { HDL-c }+ \text { VLDL-c }) . \\
& \text { Atherogenic Index }(\mathrm{AI})=\frac{\mathrm{LDL}+\mathrm{VLDL}}{\mathrm{HDL}} .
\end{aligned}
$$

\section{Histopathology examinations:}

Small specimens of the organs heart, liver and kidney were taken from each experimental group, fixed in neutral buffered formalin, dehydrated in ascending concentration of ethanol (70,80 and 90\%), cleared in zylene and embedded in paraffin. Sections of 4-6 $\mu \mathrm{m}$ thickness were prepared and stained with hematoxylin and eosin according to Bancroft and Gamble (2008).

\section{Statistical analysis:}

The results are recorded as mean \pm SD .Data were subjected to analysis of variance (ANOVA) for a completely randomized design using a statistical analysis system S.A.S (2000). Duncan's multiple range tests were used to determine the differences among means at the level of $95 \%$.

\section{RESULTS AND DISCUSSION}

\section{Proximate chemical composition of avocado fruit powder.}

Proximate chemical composition of avocado powder is recorded in Table (1). The chemical components of avocado powder were $6,6.31,49.04,8.74,22.68$ and 7.23 $\mathrm{g} / 100 \mathrm{~g}$, for moisture, protein, fat, ash, fiber and carbohydrate, respectively. These results are in agreement with Alghamdi and Yousef, (2017). Also, Weschenfelder et al. (2015) who reported that avocado was higher in fat and MUFAs.

\section{Mineral contents of avocado fruit powder (persea Americana).}

The data in Table (2) show some mineral content of avocado powder. Avocado fruit powder contained many 
important minerals as magnesium, manganese, calcium, iron, sodium, zinc and phosphorus. The highest mineral content of avocado was recorded for magnesium, calcium and sodium. They were 3318,341.50 and 809 $\mathrm{mg} / \mathrm{kg}$, respectively. The results obtained in the present study are high in $\mathrm{Mg}, \mathrm{Na}$ and $\mathrm{Zn}$ and lower in phosphorus than that found by Weschenfelder et al. (2015).

Identification and determination of phenolic content of avocado fruit powder extract.

Phenolic compounds of avocado fruit powder are shown presented in Table (3). Twenty-one compounds of phenolics were identified in dried avocado powder extract. Catechin and caffeic acid were the dominant being 80403 and 60314.4 ppm, respectively. They followed by $\alpha$-amino benzoic acid and protocatchoic (29380 and 20198 ppm), respectively.

According to Mahmoud and Rezq (2013) ferulic acid and salycilic acid were lower in avocado phenolic acid since it was found to contain than less content in our results of the present study. Whereas Shehata and Soltan , (2013) reported that pyrogallol was the major compound of phenolic followed by ellagic and lowest in coumarin.

Effect of Avocado fruit powder "AP" on feed intake (g/day), body weight gain (\%) and feed efficiency ratio (g) of hypercholesterolemic rats.

Relative body weight gain (B.W.G \%), feed intake (F.I), and feed efficiency ratio (F.E.R) of all hypercholesterolemic treated groups are illustrated in Table (4).

Table 1. Proximate chemical composition (\%) of avocado fruit powder on dry weight basis

\begin{tabular}{|c|c|c|c|c|c|c|c|}
\hline & Constituents & Moisture & protein & Fat & Ash & Fiber & Carbohydrates \\
\hline Avocado & Powder & 6 & 6.31 & 49.04 & 8.74 & 22.68 & 7.23 \\
\hline
\end{tabular}

Table 2. Mineral content of avocado fruit powder (mg/kg) on dry weight basis

\begin{tabular}{cccccccc}
\hline Sample & $\mathbf{M g}$ & $\mathbf{M n}$ & $\mathbf{C a}$ & $\mathbf{F e}$ & $\mathbf{N a}$ & $\mathbf{Z n}$ & $\mathbf{P}$ \\
\hline $\begin{array}{c}\text { Avocado } \\
\text { Powder }\end{array}$ & 3318 & 12.40 & 341.50 & 58.00 & 809 & 24.40 & 33.24 \\
\hline
\end{tabular}

Table 3. contents of individual phenolic compounds of dried avocado fruit powder extract

\begin{tabular}{lc}
\hline Identified constituents & (ppm) \\
\hline Catechol & 63.76 \\
Caffeic acid & 60314.4 \\
Vanillic acid & 46.5 \\
$3,4,5$ methoxy cinnamon & 311.43 \\
Catechin & 80403 \\
Protocatchoic & 20198 \\
Ferulic acid & 10.78 \\
Coumarin & 4.215 \\
$\beta$ - hydroxyl benzoic acid & 10.93 \\
Chlorogenic acid & 14.71 \\
$\alpha-$ amino benzoic acid & 29380 \\
Pyrogallol & 28.02 \\
Salicylic acid & 54.085 \\
$\alpha-$ coumaric acid & 94.37 \\
Ellagic acid & 9.75 \\
Benzoic acid & 32.95 \\
Oluropen & 3.764 \\
e- vanillic acid & 567.3 \\
Gallic acid & 11.32 \\
Epi-catechin & 19.56 \\
Qurestin & 88.61 \\
\hline
\end{tabular}


Mean values of BWG (\%) and FER(g) of hypercholesterolemic treated group with $25 \%$ AP were significantly lower $(\mathrm{P} \leq 0.05)$ when compared to the corresponding values in hypercholesterolemic treated groups with 10 and $15 \%$ AP respectively, and when compared with the control positive group $(\mathrm{P} \leq 0.05)$. This may be related to a high amount of fiber contained in avocado. But, mean value of FI (g/day) of hypercholesterolemic treated groups with $10,15 \%$ and $25 \%$ AP, respectively showed no significant differences among them. $(\mathrm{p} \leq 0.05)$.

Naveh et al. (2013) and Fulgoni et al. (2013) indicated that avocado consumption is associated with improved nutrient intakes and lower body weight and reducing the risk of metabolic syndrome. While, Barakat (2011) showed that avocado decreased significantly FER as compared to positive control $(+\mathrm{v})$ group.

Effect of avocado powder "AP" on serum lipid profile (TC, TG, HDL-C, LDL-C - VLDL-C and AI) of hypercholesterolemic rats.

The impact of avocado powder on lipid profile of hypercholesterolemic rats is presented in Table (5). Rats fed on high fat diet and levels of cholesterol without any addition showed significant increase $(P \leq 0.05)$ in the levels of serum cholesterol, triglyceride, very lowdensity lipoprotein cholesterol (VLDL. c), low density lipoprotein cholesterol (LDL.c) and atherogenic index (AI) compared with the normal control group while, high density lipoprotein cholesterol (HDL.c) had an opposite result. These increase in TC, TG, LDL. c, VLDL. $\mathrm{c}$ and $\mathrm{AI}$ in hypercholesterolemic rats may be related to fed the rats on $1.5 \%$ cholesterol plus $10 \%$ sheep ghee for 15 days to induce hypercholesterolemia which leading to the accumulation of lipid on blood.

The data in the same Table showed significant reduction $(\mathrm{p} \leq 0.05)$ in TC, TG, LDL.C, VLDL.C and AI levels and elevation in the level of HDL.c compared with the positive control group. This decrement could be attributed to antioxidant capacity in avocado powder which is rich in polyphenols (flavonoids and phenolic acids). Also, the results indicated that supplementation hypercholesterolemic rats with $25 \%$ of avocado powder was more effective $(\mathrm{P} \leq 0.05)$ in reducing $\mathrm{TC}$, TG, LDL.C, VLDL.C and AI than those supplemented with 10 and $15 \%$, AP.

These results are in agreement with those obtained by Mohammed (2011) who revealed that the avocado

Table 4. The effect of avocado fruit powder "AP" on feed intake (g/day), relativ body weight gain(\%) and feed efficiency ratio (g) of hypercholesterolemic Rats

\begin{tabular}{lccc} 
& & & \\
Groups & Feed Intake (g/day) & BWG(\%) & FER (g) \\
\hline G1 Control (-) & $16.9 \pm 0.3^{\mathrm{c}}$ & $22.17 \pm 0.02^{\mathrm{b}}$ & $0.041 \pm 0.002^{\mathrm{b}}$ \\
G2 Control (+) & $19.7 \pm 0.5^{\mathrm{a}}$ & $36.73 \pm 0.12^{\mathrm{a}}$ & $0.072 \pm 0.001^{\mathrm{a}}$ \\
G3 (10\%AP) & $17.3 \pm 0.31^{\mathrm{b}}$ & $6.21 \pm 0.07^{\mathrm{c}}$ & $0.014 \pm 0.002^{\mathrm{d}}$ \\
G4 (15\% AP) & $17.9 \pm 0.1^{\mathrm{b}}$ & $6.88 \pm 0.05^{\mathrm{c}}$ & $0.016 \pm 0.002^{\mathrm{c}}$ \\
G5 (25\%AP) & $18 \pm 0.3^{\mathrm{b}}$ & $4.81 \pm 0.01^{\mathrm{d}}$ & $0.011 \pm 0.001^{\mathrm{e}}$ \\
\hline
\end{tabular}

All results are expressed as mean \pm SD.

Values in each column which have different superscript letters are significantly different at $\mathrm{P} \leq 0.05$.

BWG: Body Weight Gain FI: Feed Intake FER: Feed Efficiency Ratio

Table 5. The effect of avocado fruit powder "AP" on serum lipid profile (TC ,TG, HDL-C, LDL-C - VLDL-C and AI) of hypercholesterolemic rats

\begin{tabular}{|c|c|c|c|c|c|c|}
\hline Groups & $\begin{array}{c}\text { TC } \\
\mathrm{Mg} / \mathrm{dl}\end{array}$ & $\begin{array}{c}\text { TG } \\
\mathbf{M g} / \mathrm{dl}\end{array}$ & $\begin{array}{l}\text { HDL-c } \\
\text { Mg/dl }\end{array}$ & $\begin{array}{l}\text { LDL-c } \\
\text { Mg/dl }\end{array}$ & $\begin{array}{c}\text { VLDL-c } \\
\text { Mg/dl }\end{array}$ & AI \\
\hline G1 Control (-) & $89.96 \pm 2^{\mathrm{d}}$ & $50.8 \pm 2.1^{\mathrm{d}}$ & $65.6 \pm 1.1^{\mathrm{a}}$ & $14.16 \pm 2.3^{\mathrm{d}}$ & $10.16 \pm 0.4^{\text {cd }}$ & $0.36 \pm 0.035^{\mathrm{c}}$ \\
\hline G2 Control (+) & $140 \pm 2.3^{\mathrm{a}}$ & $118.6 \pm 24^{\mathrm{a}}$ & $24.4 \pm 2.7^{\mathrm{d}}$ & $91.8 \pm 3^{\mathrm{a}}$ & $23.7 \pm 0.4^{\mathrm{a}}$ & $4.78 \pm 0.64^{\mathrm{a}}$ \\
\hline G3 (10\%AP) & $124.2 \pm 2^{c}$ & $71.4 \pm 2.5^{\mathrm{b}}$ & $57 \pm 1.3^{c}$ & $52.9 \pm 3^{\mathrm{c}}$ & $14.28 \pm 0.5^{\mathrm{b}}$ & $1.17 \pm 0.01^{\mathrm{b}}$ \\
\hline G4 (15\% AP) & $131.01 \pm 0.33^{b}$ & $62.8 \pm 2.3^{\mathrm{c}}$ & $60.2 \pm 1.3^{\mathrm{b}}$ & $58.24 \pm 2.1^{\mathrm{b}}$ & $12.56 \pm 0.4^{c}$ & $1.17 \pm 0.2^{\mathrm{b}}$ \\
\hline G5 (25\%AP) & $126.4 \pm 0.63^{\mathrm{c}}$ & $51 \pm 1.5^{\mathrm{d}}$ & $58.3 \pm 0.9 b^{c}$ & $57.9 \pm 2^{\mathrm{b}}$ & $10.2 \pm 0.3^{\mathrm{cd}}$ & $1.16 \pm 0.2^{\mathrm{b}}$ \\
\hline
\end{tabular}

All results are expressed as mean \pm SD.

Values in each column which have different superscript letters are significantly different at $\mathrm{P} \leq 0.05$.

HDL-c: High Density Lipoprotein cholesterol, VLDL-c: Very Low Density Lipoprotein cholesterol, LDL-c: Low Density Lipoprotein cholesterol. 
pulp at doses of 1 and $2 \mathrm{ml} /$ day/rat caused a significant decrease in the serum lipid including TC and TG levels but showed significant increase in HDL-c. Also, Wang et al. (2015) found that the diet rich in avocado had effects on serum cholesterol level. Additionally, Dreher and Adrienne (2013) showed that the avocado had the highest fruit lipophilic antioxidant capacity, which reduced the serum lipid peroxidation and promoting vascular health. Also, Boshtam et al. (2013) found that avocado may modify the structure of the HDL lipoprotein by increasing paraoxonase 1 (PON1) enzyme activity, the cardio protector effect of HDL-cholesterol is in part due to PON1 activity, which is responsible for the hydrolysis of lipid hydroperoxides (products of the lipid oxidation)

Effect of avocado fruit powder "AP" on liver functions (AST-ALT and ratio of AST/ALT u/l) of hypercholesterolemic rats.

The impact of avocado fruit powder on liver functions of hypercholesterolemic rats is presented in Table (6). The effect of avocado powder on AST, AlT and AST/AIT of the hypercholesterolemic rats showed that the mean value AST, AlT and AST/AlT of the positive control (+) group were higher than those of the negative control (-) group being $154 \pm 6.10,49.61 \pm 0.7$ and $3.10 \pm 0.08 \mathrm{u} / \mathrm{l}$ respectively, this may be revealed to a high levels of cholesterol which can cause heart disease. They also overloaded the liver leading to fatty liver and liver damage. On the other hand supplementation of hypercholesterolemic rats with avocado powder can alleviate the serum levels of AST , ALT and AST/ ALT as well as these enzymes levels showed decreasing values with increasing doses of avocado powder whereas supplementation of hypercholesterolemic rats with $25 \%$ avocado fruit powder decreased the serum levels of AST, ALT and AST/ ALT by $(57.8 \pm 1.3,30.12 \pm 1.2$ and $1.91 \pm 0.12 \mathrm{u} / \mathrm{l})$ respectively comparing with the positive control group.

The result obtained in Table (6) agreed with Mahmoud and Rezq (2013) who reported that administration of variety concentration level of dried avocado caused lower of serum AST and ALT content compared to positive control (+ve) .Also, Mohammed (2011) indicated that rats which consumed 1 or $2 \mathrm{ml} /$ day avocado extract showed a decrement in AST and ALT activity compared to +ve group. In addition, Al-Dosari (2011) found that feeding on high cholesterol diet with avocado fruit resulted in significant decrement in liver function enzymes.

Effect of avocado fruit powder "AP" on kidney functions (serum creatinine and urea) $\mathrm{mg} / \mathrm{dl}$ of hypercholesterolemic rats.

The impact of avocado fruit powder on kidney functions of hypercholesterolemic rats are shown in Table (7). Serum creatinine and urea levels were significantly lowering in the positive control group rats as compared to those of the control negative group.

Table 6. The effect of avocado fruit powder "AP" on liver functions (AST- ALT and AST/ALT u/l )of hypercholesterolemic rats

\begin{tabular}{|c|c|c|c|}
\hline $\begin{array}{ll}\text { Groups } & \text { Parameters } \\
\end{array}$ & AST & ALT & AST/ALT \\
\hline G1 Control (-) & $49.31 \pm 1.01^{\mathrm{e}}$ & $19.1 \pm 0.5^{\mathrm{e}}$ & $2.58 \pm 0.12^{\mathrm{b}}$ \\
\hline G2 Control (+) & $154 \pm 6.10^{\mathrm{a}}$ & $49.61 \pm 0.7^{\mathrm{a}}$ & $3.10 \pm 0.08^{\mathrm{a}}$ \\
\hline G3 (10\%AP) & $75.33 \pm 2.1^{b}$ & $36.3 \pm 2.5^{\mathrm{c}}$ & $2.07 \pm 0.08^{c}$ \\
\hline G4 (15\% AP) & $64.1 \pm 1.2^{\mathrm{c}}$ & $41.98 \pm 0.8^{\mathrm{b}}$ & $1.52 \pm 0.06^{\mathrm{e}}$ \\
\hline G5 (25\%AP) & $57.8 \pm 1.3^{\mathrm{d}}$ & $30.12 \pm 1.2^{\mathrm{d}}$ & $1.91 \pm 0.12^{\mathrm{d}}$ \\
\hline
\end{tabular}

All results are expressed as mean \pm SD.

Values in each column which have different superscript letters are significantly different at $\mathrm{p} \leq 0.05$.

Table 7. The effect of avocado fruit powder "AP" on kidney functions (serum creatinine and urea ) of hypercholesterolemic rats

\begin{tabular}{|c|c|c|c|}
\hline Groups & Parameters & $\begin{array}{c}\text { S. creatinine } \\
\mathrm{Mg} / \mathrm{dl}\end{array}$ & $\begin{array}{c}\text { Urea } \\
\text { Mg/dl }\end{array}$ \\
\hline G1 Control (-) & & $0.7 \pm 0.02^{\mathrm{e}}$ & $26.2 \pm 1^{d}$ \\
\hline G2 Control (+) & & $1.61 \pm 0.01^{\mathrm{a}}$ & $65.11 \pm 0.55^{\mathrm{a}}$ \\
\hline G3 (10\%AP) & & $0.97 \pm 0.03^{b}$ & $62.1 \pm 0.5^{b}$ \\
\hline G4 (15\% AP) & & $0.91 \pm 0.01^{\mathrm{d}}$ & $52.9 \pm 1^{\mathrm{c}}$ \\
\hline G5 (25\%AP) & & $0.93 \pm 0.01^{\mathrm{c}}$ & $52.21 \pm 0.5^{\mathrm{c}}$ \\
\hline
\end{tabular}

All results are expressed as mean \pm SD.

Values in each column which have different superscript letters are significantly different at $\mathrm{P} \leq 0.05$. 
The increase in the level of creatinine and urea could be due to the cause of the renal dysfunction resulting from exposure to cholesterol and high fat diet .On the other hand, the results indicated that there were significant decrease $(\mathrm{P} \leq 0.05)$ in the level of creatinine and urea in hypocholeserolic rats treated with avocado fruit powder (AP) when compared with positive control (+ve ) group and this decrease in the level of creatinine and urea showed an increasing inclination with increasing dose of (AP) . This improvement in renal functions may be due to antioxidants and phenolic compounds present in avocado which protect against renal injury. Also, the lowest level of creatinine and urea in hypercholesterolemic rats were obtained with the group fed $25 \%$ of AP.

In this respect, the elevated level of urea in rats fed on high fat diet is likely due to the increase of amino acid catabolism which impaired kidney function or liver damage (Lietyz and Finley, 1983). The results obtained in the present study agreed with Alghamdi and Yousef (2017). They showed that rat fed on diet fortified with avocado reducing kidney functions compared with the positive control group.

\section{Histopathological examination}

\section{Liver:}

Microscopically, liver of the negative control (-) rat revealed the normal liver structure, central vein, hepatic sinusoids and hepatocytes (photo1). Meanwhile, liver of the positive control (+) rat showed multiple fat globules in hepatic sinusoids and vacuolar degeneration in hepatocytes cytoplasm, dilated sinusoids engorged with blood and contain multiple fat globules in addition to vacuolar degeneration in some hepatic cells and few inflammatory cells in filtration were detected (photo2,3). Examined sections of rat from $10 \%$ avocado fruit powder, $15 \%$ avocado powder and $25 \%$ avocado fruit powder group revealed no histopathological changes (photos 4,5,6).

\section{Kidney:}

Microscopically, kidneys of the control (-) rat the revealed the normal histological structure of renal parenchyma (photo 7). Meanwhile, kidneys of the positive control (+) rat showed vacuolar degeneration of epithelial lining renal tubules and interstitial nephritis (photos 8). However, kidneys of rats from $15 \%$ avocado powder group, $25 \%$ avocado group revealed no histopathological changes (photos 9,10). Some examined sections from $10 \%$ avocado fruit powder group showed congestion of renal blood vessels, vacuolar degeneration of epithelial lining renal tubules (photos 11).

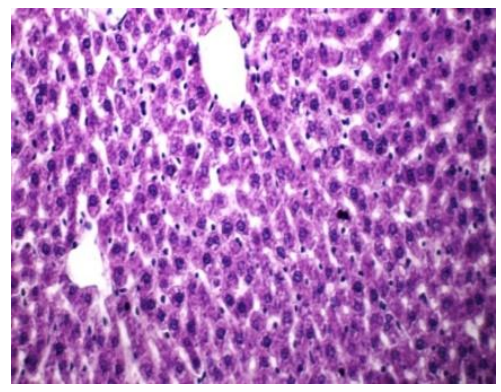

Photo 1. liver of control (-) rat group showing normal liver structure, central vein, hepatic sinusoids and hepatocytes (H and E X400)

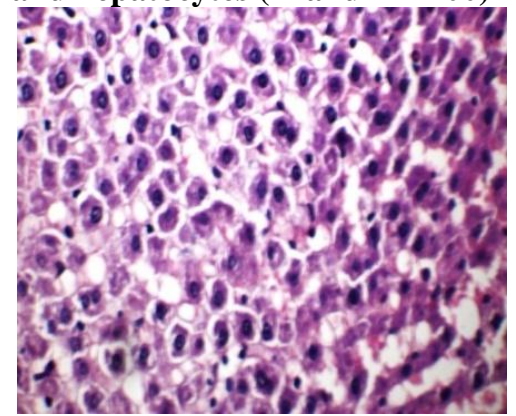

Photo 2. liver of control (+) rat group showing multiple fat globules in hepatic sinusoids and vacuolar degeneration in hepatocytes cytoplasm $(H$ and EX 400)

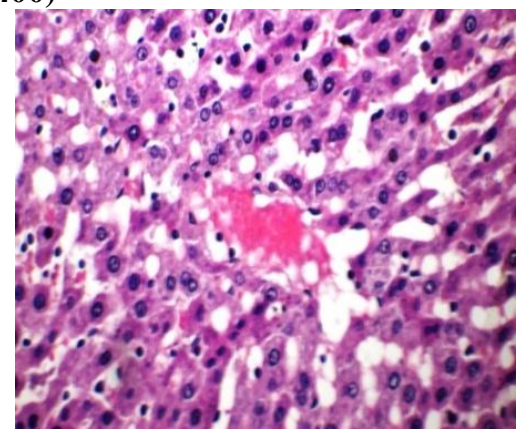

Photo 3. liver of control (+) rat group showing dilated sinusoids engorged with blood and contain multiple fat globules in addition to vacuolar degeneration in some hepatic cells and few inflammatory cells infiltration ( $\mathrm{H}$ and EX400)

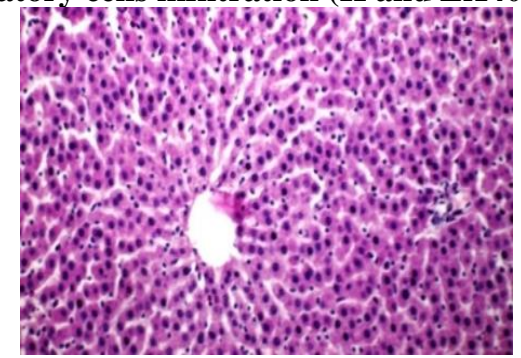

Photo 4. liver of rat from $10 \%$ avocado fruit powder group showing no histopathological changes ( $\mathrm{H}$ and EX400) 


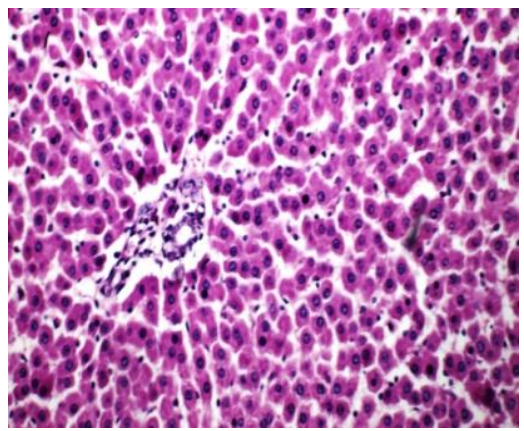

Photo 5. liver of rat from $15 \%$ avocado fruit powder group showing no histopathological changes $(\mathrm{H}$ and EX 400)

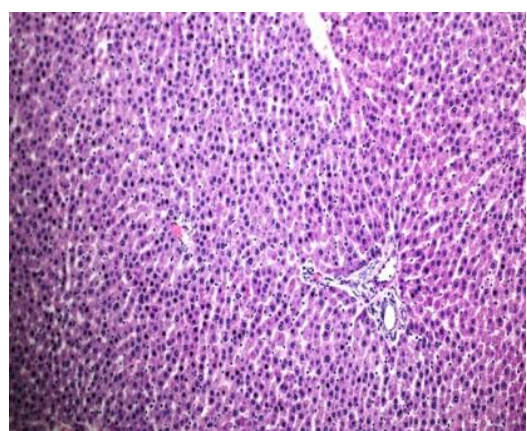

Photo 6. liver of rat from $25 \%$ avocado group showing no histopathological changes (H and EX 400)

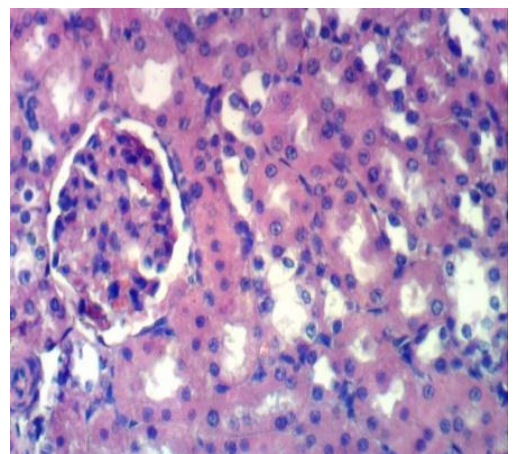

Photo 7. Kidney of control (-) rat group showing the normal histological structure of renal parenchyma (H and E X 400)

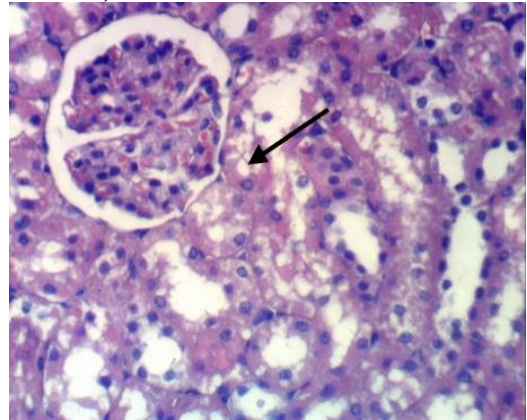

Photo 8. Kidney of control (+) rat group showing vacuolar degeneration of epithelial lining renal tubules (H and E X 400)

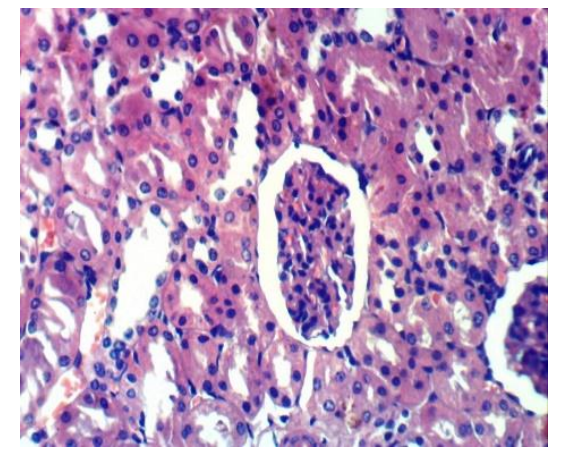

Photo 9. Kidney of rat from group $15 \%$ avocado fruit powder group showing no histopathological changes ( $H$ and $E X$ 400)

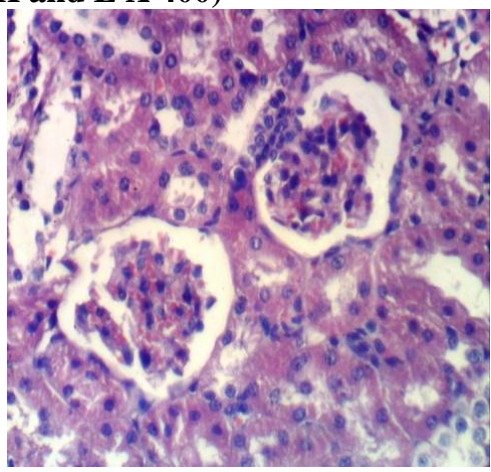

Photo 10. Kidney of rat from $25 \%$ avocado fruit powder group showing no histopathological changes (H and E X 400)

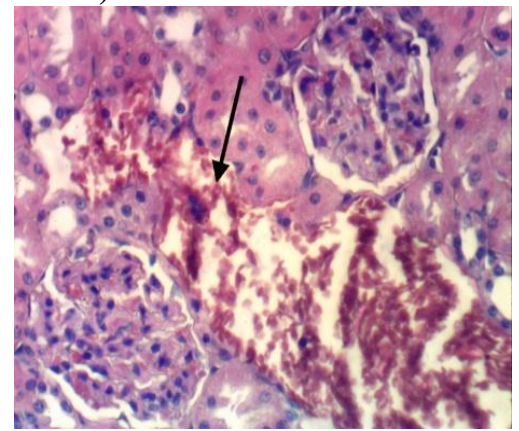

Photo 11. Kidney of rat from $10 \%$ avocado fruit powder group showing dilatation and congestion of renal blood vessels ( $H$ and $E X$ 400)

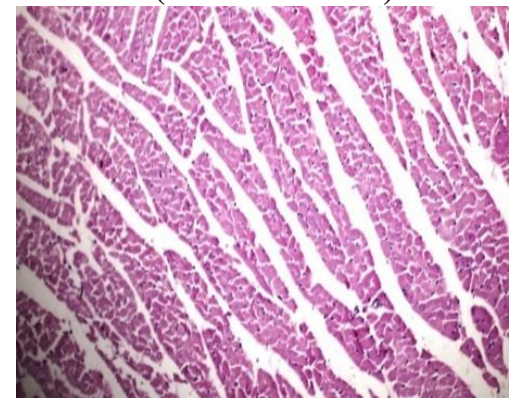

photo 12. Heart of the control (-) rat showing normal cardiac muscle fibers ( $H$ and $E X$ 400) 


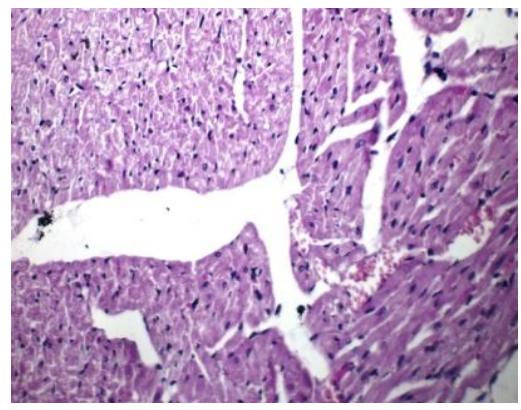

Photo 13. Heart of the control (+) rat showing vacuolar degeneration in the cytoplasm of cardiac muscle fibers and congestion in cardiac blood vessels (H and EX400)

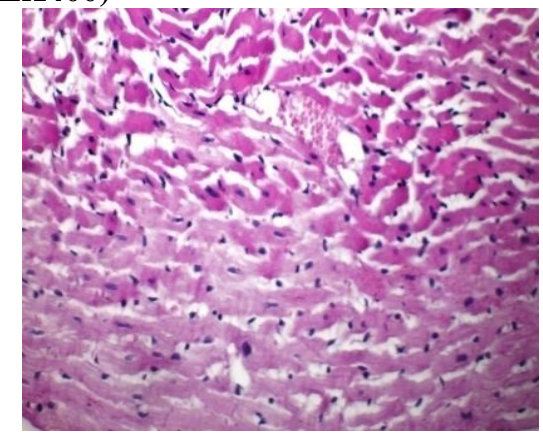

Photo 14. Heart of the control (+) rat showing sever hyaline degeneration in cardiac muscle fibers and fat globules in cardiac blood capillaries (HandEX400)

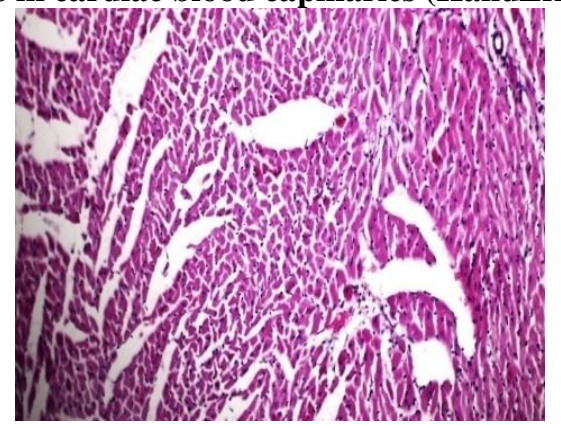

Photo 15. heart of rat from 15 avocado powder group showing no histopathological changes (HandEX400)

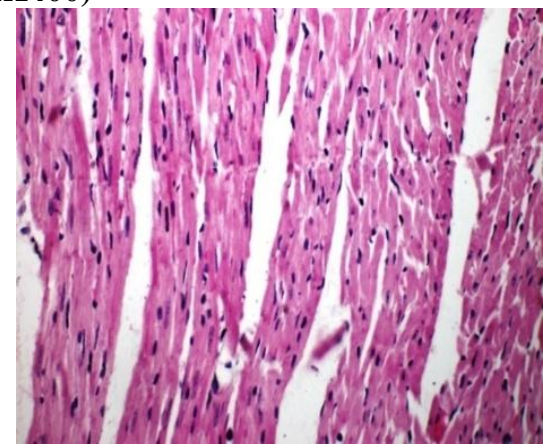

Photo 16. heart of rat from $25 \%$ avocado powder group showing no histopathological changes (Hand EX400)

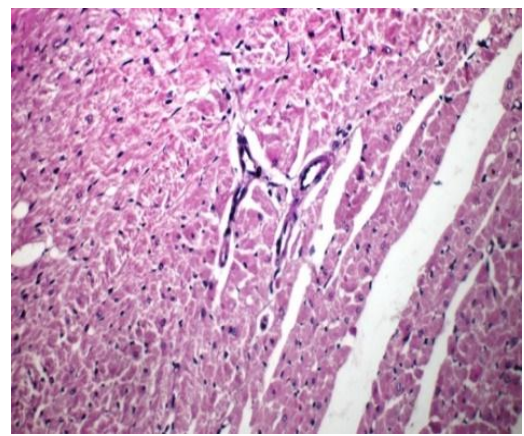

Photo 17. Heart of rat from $10 \%$ avocado fruit powder group showing mild degeneration in cardiac muscle fibers ( $\mathrm{H}$ and $\mathrm{EX} 400$ )

\section{Heart:}

Microscopically, heart of the negative control (-) rat revealed the normal cardiac muscle fibers (photo12). meanwhile, heart of control (+) rat showed vacuolar degeneration in the cytoplasm of cardiac muscle fibers, congestion in cardiac blood vessels and sever hyaline degeneration in cardiac muscle fibers, fat globules in cardiac blood capillaries (photos 13 and 14). Howe ever, heart of rats from $15 \%$ avocado powder, $25 \%$ avocado fruit powder group revealed no histopathological changes (photos 15,16). some examined sections from $10 \%$ avocado fruit powder group showed vacuolar degeneration in cytoplasm of muscle fibers, mild degeneration in cardiac muscle fibers and few hyaline degenerations in cardiac muscle fibers (photos 17).

\section{CONCLUSION:}

Avocado is one of bioactive fruit has a high amount of monounsaturated fatty acid flavonoids, phenolic compounds and vital minerals has appositive effects on metabolic factories, and has the capability to decline total cholesterol, triglycerides, LDL-c and increased HDL-c. At the same time, improve the functions of liver and kidney of hypercholesterolemic rats.

\section{REFERENCES}

AIN, A. 1993. American institute of nutrition purified diet for laboratory rodent: final report to J. Nutrition. 123: 19391951.

Al-Dosari, M. 2011. Hypolipidemic and antioxidant activities of avocado fruit pulp on high cholesterol fed diet in rats. Afr.J. Pharm. Pharmacol. 5(12):1475-1483.

Alghamdi, E.S. and F.M.A. Yousef. 2017. Effect of avocado on serum lipids of hyperlipidemic rats. Current Science International. 1(6):199-207.

Aljenedil, S., I. Ruel, D. Brisson, Z.Awan, A. Baass, A.Bélanger, D.Bewick, J. Bergeron, J.Brophy, R.L. Brunham, P.Couture, R.Dufour, A.G. Francis, J.Frohlich, C.e. Gagné, D. Gaudet, R.Hegele, G.B. Mancini, C. J. Grégoire and J. Genest. 2018. Canadian Definition for 
Familial Hypercholesterolemia. Atherosclerosis Supplements. 32. 55-56.

Allain, C. C., L. S. Poon, C. S. G.Chan, W. Richmond and P.C. Fu. 1974. Enzymatic determination of total serum cholesterol. Clin. Chem. 20(4): 470-475.

A.O.A.C. 2012. International Official Methods of Analysis. $19^{\text {th }}$ ed., Gaithersburg, MD: AOAC International.

Bancroft, J. D. and M. Gamble. 2008 Theory and practice of histology techniques, 6th ed. Philadelphia: Churchill Livingstone Elsevier. pp. 83-134.

Barakat, L. 2011. Hypolipidemic and Antiatherogenic Effect of dietary chitosan and wheatbran in high fat - high cholesterol fed rats. Australian journal of basic and applied sciences. 5(10):30-37.

Boshtam, M., A.E. Razavi, M. Pourfarzam, M. Ani, G.A. Naderi, G.Basati. 2013. Serum paraoxonase activity is associated with fatty acid composition of high-density lipoprotein. Diseases Markers. 35:273-280.

Champman, D. G., R.Gastilla and J. A. Cambell. 1959. Evaluation of protein in food. LA. method for the determination of protein efficiency ratio. Can. J. Biochem. Phosiol. 37:679-686.

Chawla, R. 2003. Practical clinical biochemistry. Third Edition Jaypee Brothers Medical Publichers (p) LTD, New Delhi.

Demacker, P. M., H. E. Von-Janssen, A. M.Hifman, A. Vant's Lear and A. P. Jansen. 1980. Measurement of high-density lipoprotein cholesterol in serum. Comparison of six isolation methods combined with enzymatic cholesterol analysis. Clin. Chem. 26: 1780-1789.

Dreher, M. and J.Adrienne. 2013. Hass avocado composition and potential health effects. Critical Reviews in Food Science and Nutrition. 53(7):738-50.

Fossati, P. and I. Prencipe. 1982. Serum triglycerides determination colorimetrically with an enzyme that produce hydrogen peroxide. Clin. Chem. 28: 2077-2083

Fulgoni, V.M., M. Dreher, A. Davenport. 2013. Avocado consumption is associated with better diet quality and nutrient intake and lower metabolic syndrome risk in US adults: results from the national health and nutrition examination survey (NHANES)2001-2008 Nutr.J. 2 :12-1.

Hamouda, A. F., M. Y. Sameeh and R. M. Shrourou. 2016. Effect of avocado (Persea Americana), Cabbage (Brassica Oleracea) and Ginger (Zingiber Officinale) on rat liver and thyroid injuries induced by $\mathrm{CCl} 4$ (Carbon Tetrachloride). J. of Phar and Pharmaco. 4 :108-118.

Haralambos, K., P. Ashfield-Watt and I.F. McDowell. 2016. Diagnostic scoring for familial hypercholesterolaemia in practice. Curr Opin Lipidol. 27: 367-374.

Jendrassik, L. P. and P. Grof. 1983. Vereinfachte photometrische methoden zur bestimmung des blutbilirubins. Biochemische Zeitschrift Band. 297: 8189.
Lee. R. and D. Nieman. 1996. Nutrilional Assessment. 2 nd, Mosby, Missouri. USA.

Lietyz, N.W. and P.R. Finley. 1983. Clinical guide to laboratory tests section. W.B. saunders Company. 493495.

Mahmoud, M. and A. Rezq. 2013. Hepatoprotective effect of avocado fruits against carbon tetrachloride-induced liver damage in male rats. World Applied Sciences Journal. 21 (10): 1445-1452.

Malhotra, V.K. 2003. Practical Biochemistry for Students. Fourth Edition Jaypee Brothers Medical Publishers (P) LTD. New Delhi.

Mohammed, S.A. 2011. Hypolipdemic and antioxidant activites of avocado fruit pulp on high cholesterol fed diet in rats. Afr. J. Pharm. Pharmacol. 5(12): 1475-1483.

Naveh, E., M.Werman, E. Sabo and I. Neeman. 2013. Defatted avocado pulp reduces body weight and total hepatic fat but increases plasma cholesterol in male rats fed diets with cholesterol. J. nutrition. org. 132(7):2015-8.

Patton, C.J. and S.R. Crouch 1977. Enzymatic determination of urea. J. of Anal. Chem. 49: 464-469.

Radovanović, B.C., A.N. Radovanović and J.M. Souquet. 2010. Phenolic profile and free radical-scavenging activity of Cabernet Sauvignon wines of different geo graphical origins from the Balkan region. J. Sci. Food Agric. 90: $2455-2461$.

Roman, W.A., A.L.Piato, G.M.Conterato, S.M. Wildner, M. Marcon, R. Mocelin, M.P. Emanuelli, T. Emanuelli, A. Nepel and A.Barison. 2015. Hypolipidemic effects of Solidago chilensis hydroalcoholic extract and its major isolated constituent quercetrin in cholesterol-fed rats. Pharm Biol. 53:1488-1495.

SAS. 2000. Statistics Analysis System. SAS Users Guide: Statistics Version5th Ed., SAS. Institute Inc. Cary N.C.

Shehata, M.S.M. and S.S. Soltan. 2013. Effect of bioactive component of kiwi fruit and avocado (fruit and seed) on hypercholestrolemic rats, J Dairy \& food sciences. 8(1):82-93.

Srivastava, L.M., N. Das and S. Sinha. 2002. Essentials of Practical Biochemistry. CBC Publishers and Distributors.

Wang, L., P.L. Bordi, J.A. Fleming, A.M. Hill and P.M. KrisEtherton. 2015. Effect of a moderate fat diet with and without avocados on lipoprotein particle number, size and subclasses in overweight and obese adults: A randomized, controlled trial. Journal of the American Heart Association. 4 (1): e001355.

Weschenfelder, C., J.L. dos Santos, P.A.L. de Souza, de V.P. Campos and A. Marcadenti. 2015. Avocado and cardiovascular health. Open Journal of Endocrine and Metabolic Diseases. 5(5): 77-83. 


\section{الملخص العربي}

\section{تأثيرات المركبات النشطة حيويا لمسحوق ثمار الافوكادو علي الفئران المصابة بارتفاع الكوليسترول:}

\section{در اسة بيولوجية وكيموحيويه}

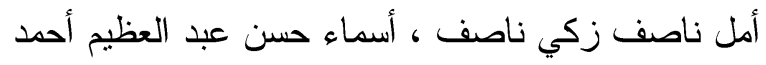

هدفت هذه الدراسة إلي توضيح تأثير التركيزات وظائف الكبد ووظائف الكلي) كما تم عمل التحليل المختلفة من مسحوق ثمار الافوكادو علي المؤشرات الهستوباثولوجي للأعضاء الهامه: للكبد، الكلي و والقلب.

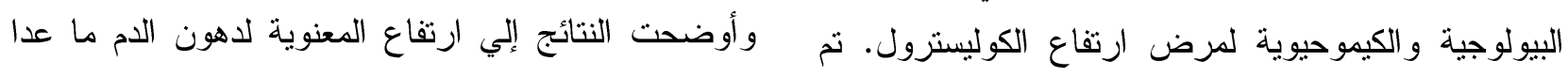

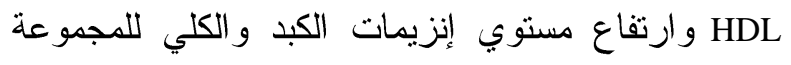

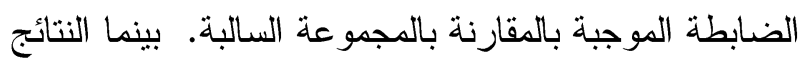

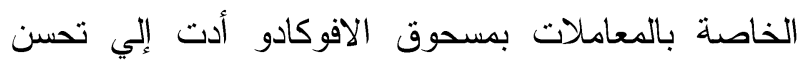

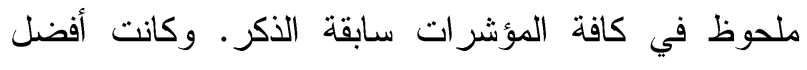

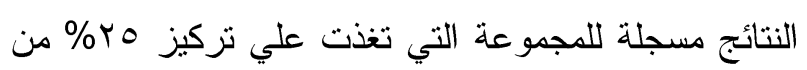

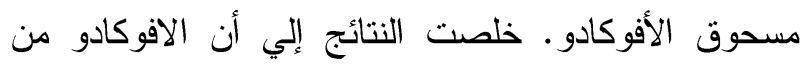

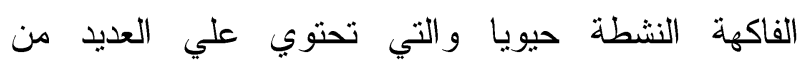

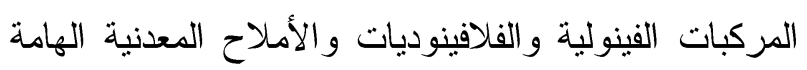

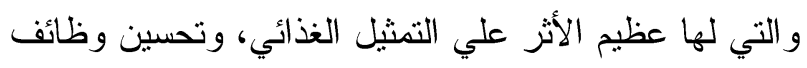

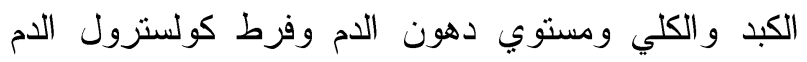
وأمر اض القلب.

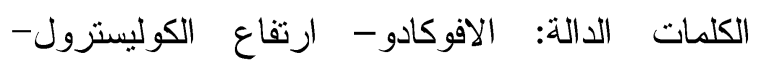
التغيرات البيولوجية - الكيموحيوية - دهون الدم - النشط

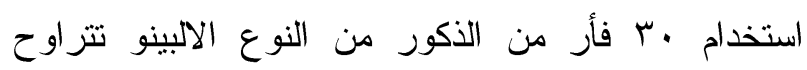

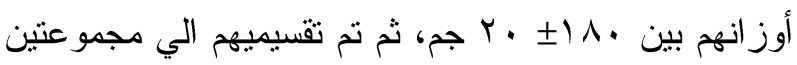

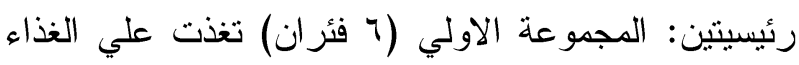

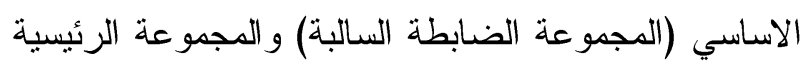

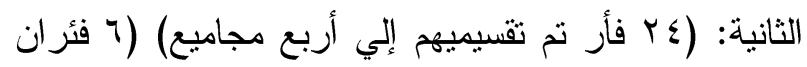

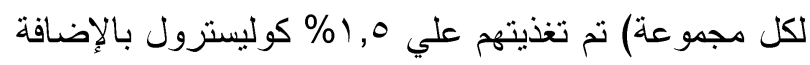

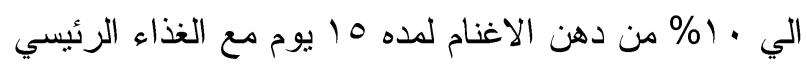

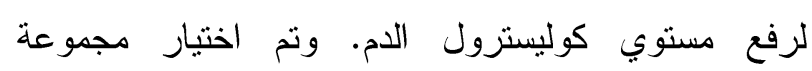
باعتبارها (المجموعة الضابطة الموجبة) وبقية المجاميع تم

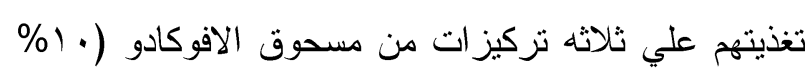

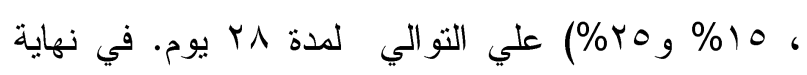
التجربة تم تقدير التركيب الكيماوي والمركبات الفعالة لثمار الافوكادو وتم قياس المؤشرات البيولوجية وهي BWG - FER -FI قياس المؤشرات الكيموحيوية وهي (مستوي دهون الدم، 